\title{
Participation and Sustainable Management of Coastal Lagoon Ecosystems: The Case of the Fosu Lagoon in Ghana
}

\author{
Frederick A. Armah ${ }^{1, *}$, David O. Yawson ${ }^{2}$, Alex N.M. Pappoe ${ }^{1}$ and Ernest K.A. Afrifa ${ }^{1}$ \\ 1 Department of Environmental Science, School of Biological Sciences, University of Cape Coast, \\ Cape Coast, Ghana; E-Mails: anmpappoe@yahoo.com (A.N.M.P.); e_afrifa@yahoo.co.uk \\ (E.K.A.A.) \\ 2 Department of Soil Science, School of Agriculture, University of Cape Coast, Cape Coast, Ghana; \\ E-Mail: oskidoo@yahoo.com
}

* Author to whom correspondence should be addressed; E-Mail: atoarmah@yahoo.com; Tel.: +233-24-9483014; Fax: +233-42-32709.

Received: 11 December 2009 / Accepted: 19 January 2010 / Published: 25 January 2010

\begin{abstract}
Participation as a tool has been applied as a social learning process and communication platform to create awareness among stakeholders in the context of resource utilisation. The application of participatory processes to aquatic ecosystem management is attracting a growing body of literature. However, the application of participation as a tool for sustainable management of coastal lagoon ecosystems is recent. This paper examines the context and the extent of participation of stakeholders in the management of the Fosu lagoon in Ghana. Six hundred individuals from twenty seven stakeholder groups were randomly selected for study. Both closed and open-ended questions were used in face-to-face interviews with stakeholders. The findings indicate that the stakeholder groups were not involved in decision-making regarding the conservation of the lagoon irrespective of their expertise in planning and/or their interest in lagoon resource utilisation. This situation has created apathy among some of the stakeholders who feel neglected in the decision-making process. There is scope for broadening the base of interest groups in decision-making processes regarding the lagoon and improving stakeholder participation in the management of the lagoon to ensure the sustainability of the management process.
\end{abstract}

Keywords: stakeholder participation; community; lagoon management; conflict; socio-ecological system; sustainability 


\section{Introduction}

Community based natural resource management (CBNRM) has received significant attention in the literature. The call for greater community participation in natural resource management and conservation by international and state natural resource agencies is premised on the supposition that local communities that have connections to, knowledge about, and interests in proximate resources should participate in the management of those resources [1-3]. A wide array of natural resources such as wildlife, fisheries, lagoons, wetlands, forests, land use, ground water resources, etc. have in one way or the other been mentioned as part of CBNRM approaches. In Sub-Saharan Africa, the emergence of the concept and practice of CBNRM has been attributed to miscellany of factors ranging from the growth of research on common pool resources and in political ecology during the last two decades; the broader views of the neo-liberal convention of market-based incentives, property rights, and decentralization; donor interests in achieving synergies between rural development and biodiversity conservation; through to the connection between local demands for greater control over resources and political decision makers' interests in reducing expenditures $[2,3]$.

It is apparent that the debate on the usefulness and level of success of CBNRM approaches across geographical regions is mixed. For instance, it is argued that CBNRM has failed on the basis of the lack of local participation, or on the lack of ecological results [4]. Other critiques of CBNRM have centred on tokenism; myths of 'communities' as homogeneous and cohesive entities; limitation of participatory approaches to development; and lack of knowledge regarding the CBNRM process and how to facilitate it [5]. However, [5-7] argue that irrespective of the limitations of CBNRM, it has been a veritable platform for bringing local communities into a globalised world in terms of practice and narrative. Again, it has been argued [8] that CBNRM approaches are mechanisms that facilitate equitable distribution of scarce resources, and make more people more accountable for environmental outcomes, therefore it is viable. The community-based approach to the stewardship of natural resources has been found to be a viable alternative to state management and can, if properly executed, effect more evenhanded distribution of power and economic benefits, reduced conflicts, increased consideration of traditional and modern environmental knowledge, protection of biological diversity, and sustainable utilization of natural resources [9].

It is also clear that the scope, context, social, political, institutional, environmental and economic underpinnings of CBNRM differ across spatial and temporal scales. The institutional and political dimensions of CBNRM and decentralized nature governance in seven east and southern African countries were examined by [2]. In this case, [2] indicate that the high financial natural resource values obtained by state agents, especially when tied to high levels of corruption, form strong disincentives for central managers to delegate power over natural resource to local communities. The different development-oriented biodiversity conservation and CBNRM approaches as they exist across Africa have also been compared and contrasted by [10]. Specifically, the fundamentals of natural resource management in relation to local development and livelihoods and the multi-functional nature of land use have been given prominence by [10]. In studying cases of CBNRM in the context of the developed countries (e.g., Sweden, Netherlands and USA) and the developing countries (e.g., Philippines, Brazil, Ecuador and Peru), [11] emphasize the need to focus on how communities are defined and how participation is formalized by institutions, as well as to contested meanings of conservation. In 
Australia, [12] have delineated some of the factors that impact positively and negatively on groups involved in CBNRM under conditions of sociopolitical and environmental change. In contributing to the foregoing debate, this paper focuses on a coastal lagoon ecosystem in Ghana.

Coastal lagoons are shallow aquatic ecosystems that develop at the interface between coastal terrestrial and marine ecosystems. They are driven to a major extent by the high density of noncommercial auxiliary energy and mass exchanges with the surrounding ecosystems [13]. The rate of structural and functional change of hydrogeomorphological units and biological communities is particularly dependent on the exchanges of auxiliary energy and mass [14]. Although lagoons are intricately connected to surrounding environments, they develop mechanisms for structural and functional regulation, which result in specific biological productivity and carrying capacities [15]. Today, many lagoons are deteriorating because of overuse of their natural capital [15-17]. The Fosu Lagoon in Ghana is a distinctive example. The recent addition of the Fosu Lagoon to the list of water bodies with 'dead zones' [36] has raised concern for the people who depend on it for their livelihood. 'Dead zones' in this context are areas where the bottom water (the water at the lagoon floor) is anoxic-meaning that it has very low (or completely zero) concentrations of dissolved oxygen. Dissolved oxygen deficits, aquatic toxicity, variation in organism structure, disappearance of benthic animals, turbidity and odours, fish mortality, sedimentation, and clogging of channels reduce the sustainability of the lagoon [18-20]. Numerous uses, which are uncontrolled and competing, have compromised the quality and the ability of the Fosu Lagoon to sustain the productivity of natural capital [18-20].

It is important to provide the best available knowledge and information in a coordinated manner to enable decisions that foster the sustainable management of the Fosu Lagoon. It is the task of decision makers to make choices that affect the lagoon system using the best available information and tools [15]. These decisions inevitably center on finding the balance between the finite capacity of the Fosu lagoon system and the many demands being placed upon it by the socio-economic system that depend on it. Further, it is imperative to establish a process or plan by which informed decisions can be made over time, and which provides consistency and ensures coordination by the multitude of users of the lagoon system regarding the future of the Fosu Lagoon.

There are examples on advocacy for the incorporation of indigenous ecological knowledge and customary institutions into lagoon management [21]. This call re-echoes earlier efforts to include local communities and their institutions in decentralized participatory lagoon management $[22,23]$. This paper extends this line of work by demonstrating the value of understanding and promoting community participation in lagoon resource management, restoration, and ecosystem governance and the potential to be found in complementing and combining diverse knowledge systems in the management of social-ecological systems. Specifically, the paper studies the context and the extent of participation by stakeholders in the management of the Fosu Lagoon in Ghana and suggests ways to improve the participatory process.

\section{Participatory Ecosystem Management}

Participatory ecosystem management concentrates on sustainable development principles with a view to enabling protection of the ecosystem into the future. It integrates human, biological and natural 
dimensions $[24,25]$ since humans interact with or exploit biological systems and thereby impact upon natural processes that sustain the biological systems. Ecosystem management involves multifaceted technical, legal and economic issues; it also includes many stakeholders including local population, fishermen, land owners, environmentalists, industrial groups and politicians [22,23]. Therefore ecosystem management falls within the domain of multi-criteria decision-making processes. The principles and elements of participatory ecosystem management are highlighted in the table below.

Table 1. Principles and elements of participatory ecosystem management [13,14].

1. Collaboration between all who are involved in management procedure and/or have
interests in the region
General
2. Sensitivity to the particularities, aims and activities of the local population
3. Long-term management and multiple uses of the region within a specified
legal framework
4. High quality of scientific information
1. Sustainability
2. Definition of goals
3. Sound ecological principles and understanding
4. Complexity, compactness and connectedness of the ecosystem
5. Dynamic character of the ecosystem
6. Context and scale
7. Humans as components of the ecosystems
8. Adaptability and accountability

\section{Materials and Methods}

The Fosu Lagoon is a closed coastal lagoon located in Cape Coast, the capital of the Central Region of Ghana. The geographic coordinates of the lagoon are $5^{\circ} 7^{\prime} \mathrm{N}$ and $1^{\circ} 16^{\prime} \mathrm{W}$ [26]. It is a shallow brackish body of water which is separated from the sea (Gulf of Guinea) by a sand bar which is usually broken by heavy rainfall or manually as part of the rituals during the Fetu Festival in Cape Coast. Figure 1 below is a modified screenshot from Google Earth showing the Fosu Lagoon and the surrounding land uses.

\subsection{Data Collection}

Six hundred individuals from 27 stakeholder groups were randomly selected for survey. Questionnaire was the major instrument employed in the study. Face-to-face interview of stakeholders was undertaken using both closed and open-ended questions [27]. The research approach was predominantly qualitative. Instruments such as participant observation and document analysis were also used to validate responses to some of the interview questions. 
Figure 1. Image showing Fosu Lagoon and its adjoining land uses. Source: Google Earth.

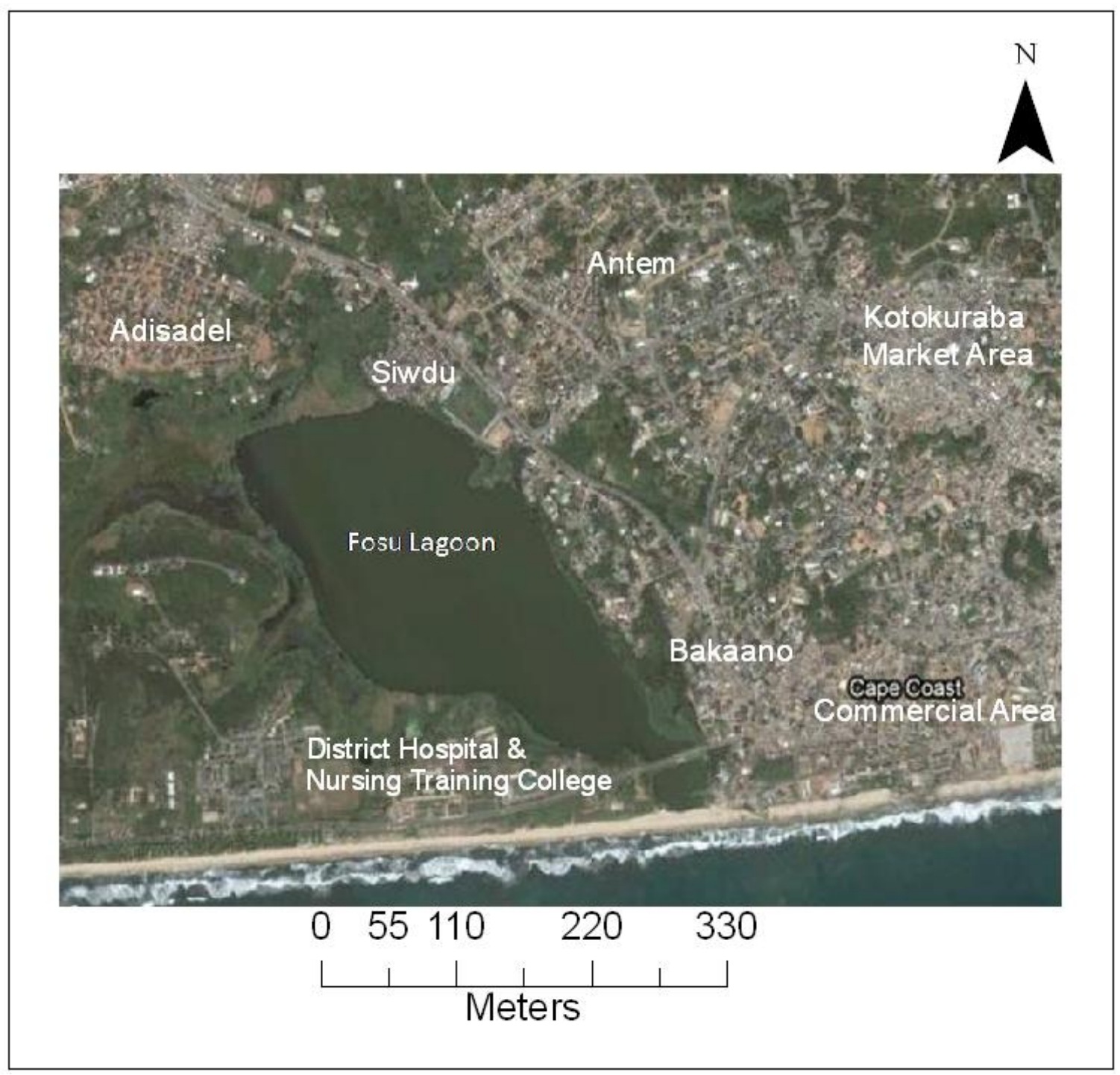

Interviews were conducted from June 2008 to December 2008 to ascertain whether individuals and stakeholder groups derived income, benefits or sources of livelihoods from the lagoon. The residents for example, dump waste into the lagoon without paying for any environmental service and some of them use the water for domestic purposes. Respondents had the option to choose one or more of the alternatives provided, or indicate other ways in which they are dependent on the lagoon. The respondents indicated the nature of their dependence on the lagoon from a set of six alternatives namely cultural, scientific value, tourism development, industry, commercial fishing, and agriculture and livestock. Even though the study employed largely a qualitative approach, the sample size was 600 and amenable to quantitative analysis. Descriptive statistics of the respondents were carried out in Microsoft excel. The extent to which respondents used the lagoon resource was assessed on a 5-point Likert-type scale ranging from 1 (not at all) to 5 (frequently). Respondents' awareness of participatory ecosystem management was measured on a 3-point Likert-type scale (3=not aware, $2=$ aware but do not participate, 3 = participate). Involvement in participatory management of the lagoon was assessed by a dichotomous variable regarding contribution to the decision-making process and if yes the 
frequency (often, sometimes, seldom) of contribution. The different stakeholder groups were asked to state the element of the lagoon ecosystem that was most important to them and whether it was essential for them to be involved in managing the lagoon. Respondents were also asked to indicate their dependence on the lagoon and relationship with other stakeholders.

\subsection{Demographic Information}

Demographic information gathered in the survey included age, gender, educational level, occupation, and number of years using the resources of the Fosu lagoon. The age of respondents ranges between 18 and 60 years. Percentages of male and female respondents were $79 \%$ and $21 \%$ respectively. Table 2 summarizes the number and type of stakeholders that were involved in the survey.

Table 2. Number of stakeholders involved in the study for each group in the population.

\begin{tabular}{|c|c|c|c|c|c|}
\hline & Number & Male & Female & Age & Occupation/Position \\
\hline Local Decision Makers & \multicolumn{5}{|l|}{$\mathrm{N}=40$} \\
\hline 1. Bakaano & 8 & 8 & - & $40-45$ & Opinion leader, family head, clan head \\
\hline 2. Adisadel Estate & 8 & 5 & 3 & $36-45$ & $\begin{array}{l}\text { Assembly member, family head, } \\
\text { opinion leader }\end{array}$ \\
\hline 3. Siwdu & 8 & 7 & 1 & $28-40$ & Assembly member, family head \\
\hline 4. OLA Estates & 8 & 6 & 2 & $30-48$ & Opinion leader, assembly member \\
\hline 5. Antem & 8 & 8 & - & $42-55$ & Religious head, unit committee member \\
\hline Residents in Nearby Areas & \multicolumn{5}{|l|}{$\mathrm{N}=280$} \\
\hline 1. Bakaano & 40 & 30 & 10 & $25-45$ & $\begin{array}{l}\text { Teacher, student, seamstress, tailor, } \\
\text { auto mechanic }\end{array}$ \\
\hline 2. Adisadel Estate & 40 & 35 & 5 & $30-50$ & $\begin{array}{l}\text { Trader, banker, civil servant, caterer, } \\
\text { car washer }\end{array}$ \\
\hline 3. Siwdu & 40 & 32 & 8 & $25-40$ & $\begin{array}{l}\text { Welder, trader, metallurgist, auto mechanic, } \\
\text { petrol station attendant }\end{array}$ \\
\hline 4. OLA Estates & 40 & 25 & 15 & $28-42$ & $\begin{array}{l}\text { Engineer, chemist, teacher, mason, tailor, } \\
\text { clergy }\end{array}$ \\
\hline 5. Antem & 40 & 36 & 4 & $40-50$ & Mason, fishermen, trader, welder \\
\hline 6. St Augustine College & 40 & 28 & 12 & $28-52$ & Teacher, student, caterer, labourer \\
\hline 7. Nurses Training College & 40 & 33 & 7 & $22-48$ & Teacher, student, principal \\
\hline Civil Society & \multicolumn{5}{|l|}{$\mathrm{N}=12$} \\
\hline $\begin{array}{l}\text { 1. Ghana Heritage } \\
\text { Conservation Trust }\end{array}$ & 4 & 4 & - & $38-42$ & $\begin{array}{l}\text { Programmes coordinator, conservationist, } \\
\text { executive director }\end{array}$ \\
\hline 2. Ghana Wildlife Society & 4 & 4 & - & $35-40$ & Patron, programmes officer \\
\hline 3. WasteWise Ghana & 4 & 4 & - & $28-36$ & $\begin{array}{l}\text { Deputy executive director, programmes } \\
\text { coordinator }\end{array}$ \\
\hline Government Officials & \multicolumn{5}{|l|}{$\mathrm{N}=44$} \\
\hline $\begin{array}{l}\text { 1. Cape Coast Municipal } \\
\text { Assembly (CCMA) }\end{array}$ & 16 & 10 & 6 & $30-45$ & $\begin{array}{l}\text { Water and sanitation officer, engineer, waste } \\
\text { management expert, presiding member, } \\
\text { environmental health specialist }\end{array}$ \\
\hline
\end{tabular}


Table 2. Cont.

\begin{tabular}{|l|c|c|c|c|l|}
\cline { 2 - 6 } \multicolumn{1}{l|}{} & Number & Male & Female & Age & Occupation/Position \\
\hline $\begin{array}{l}\text { 2. Environmental Protection } \\
\text { Agency (EPA) }\end{array}$ & 8 & 6 & 2 & $30-50$ & $\begin{array}{l}\text { Field officers, program officers, } \\
\text { environmental planner, chemist, } \\
\text { environmental monitor }\end{array}$ \\
\hline $\begin{array}{l}\text { 3. Central Regional } \\
\text { Coordinating Council } \\
\text { (CRCC) }\end{array}$ & 4 & 4 & - & $35-55$ & $\begin{array}{l}\text { Director, budget officer, tourism committee } \\
\text { member }\end{array}$ \\
\hline $\begin{array}{l}\text { 4. Central Regional } \\
\text { Development Commission } \\
\text { (CEDECOM) }\end{array}$ & 8 & 7 & 1 & $24-50$ & $\begin{array}{l}\text { Budget officer, development planner, } \\
\text { project officer }\end{array}$ \\
\hline $\begin{array}{l}\text { 5. Ghana Tourism Board } \\
\text { (GTB) }\end{array}$ & 8 & 5 & 3 & $25-48$ & $\begin{array}{l}\text { Development officer, conservationist, } \\
\text { environmental educator }\end{array}$ \\
\hline Other Interest Groups & $\mathrm{N}=224$ & \multicolumn{5}{|c|}{} & & & & & & \\
\hline 1. Sand Miners & 20 & 20 & - & $28-48$ & - \\
\hline 2. Fishermen & 100 & 100 & - & $18-60$ & Canoe owner, artisanal fishermen \\
\hline 3. Fish Mongers & 20 & 2 & 18 & $20-42$ & - \\
\hline 4. Traders & 20 & - & 20 & $22-45$ & Retailer, petty trader \\
\hline 5. Traditional Authorities & 10 & 8 & 2 & $40-50$ & Priest, priestess, landowner, chief \\
\hline 6. Garages \& Workshops & 40 & 40 & - & $18-45$ & Workshop owner, apprentices \\
\hline 7. Researchers \& Academics & 14 & 7 & 7 & $29-45$ & $\begin{array}{l}\text { Sociologist, Economist, Ecologist, } \\
\text { Geographer, Development expert }\end{array}$ \\
\hline & 600 & 474 & 126 & $18-60$ & \\
\hline
\end{tabular}

\section{Results and Discussion}

All stakeholders indicated that it was essential to take account of their views in the decision-making processes concerning the lagoon to engender better decision outcomes in terms of the quality of the decision-making process. On the lagoon use continuum, $60 \%$ of respondents use the lagoon frequently, 25\% use the lagoon infrequently, $10 \%$ did not indicate their use or non-use of the lagoon and $5 \%$ do not use the lagoon at all. As many as $60 \%$ of respondents were not aware of the processes surrounding the management of the lagoon, $25 \%$ were aware but have not previously participated while the rest were aware and have participated in the process. Individuals did not assign reasons for their non-participation in the process. Based on the connectedness of stakeholders to the lagoon and the power dynamics displayed in the context of decision-making, the stakeholders were categorized as active, passive, key, primary or secondary. Primary stakeholders refer to intended beneficiaries of the Fosu Lagoon remediation or those directly affected by Fosu Lagoon pollution, for example fishermen. Primary stakeholders are often divided by gender, social or income classes, occupational or service user groups. In this case, categories of primary stakeholders overlap (e.g., women and low-income groups). Secondary stakeholders refer to intermediaries who monitor, advocate, fund or implement Fosu Lagoon remediation, for example civil society. They can be divided into funding, implementing, monitoring and advocacy organisations, or simply governmental, NGO and private sector organisations. It is noteworthy that there may be some informal groups of people who will act as 
intermediaries. For example, politicians, local leaders, respected persons (opinion leaders) with social or religious influence. Key stakeholders involve agencies that significantly influence the success of the Fosu Lagoon restoration. Therefore, key and secondary stakeholders could overlap. Those that affect or determine a decision or action in relation to the Fosu Lagoon are considered as active stakeholders. A typical example is the municipality. Passive stakeholders refer to individuals or groups affected by decisions and/or actions of active stakeholders. This classification of stakeholders is in agreement with the scheme put forward by [28]. Table 3 summarizes the diverse interests in the Fosu Lagoon and the feedbacks that emanate from the Fosu Lagoon resource use. In the Ghanaian context, a fisherman is one who fishes at sea and not in-land fishing activity such as fishing in the lagoon. In this paper, however, fisherman is used to represent an individual who derives economic benefits from fishing regardless of whether it is at sea or in-land.

Table 3. Diverse interests of stakeholders and dependencies on the Fosu Lagoon.

\begin{tabular}{|c|c|c|c|c|}
\hline Stakeholder & Characteristics & $\begin{array}{c}\text { Resource Use and } \\
\text { Feedback }\end{array}$ & $\begin{array}{l}\text { Dependency } \\
\text { on Lagoon }\end{array}$ & Interest \\
\hline $\begin{array}{l}\text { Fishing } \\
\text { Community }\end{array}$ & $\begin{array}{l}\text { Primary but } \\
\text { passive }\end{array}$ & $\begin{array}{l}\text { Fish harvesting, use of } \\
\text { water, depletion of fish } \\
\text { stock, depletion of } \\
\text { water volume }\end{array}$ & Direct & $\begin{array}{l}\text { Economic benefits (access to, and } \\
\text { harvesting of fish) }\end{array}$ \\
\hline Sand Miners & $\begin{array}{l}\text { Primary but } \\
\text { passive }\end{array}$ & $\begin{array}{l}\text { Winning and sale of } \\
\text { sand, erosion of soil }\end{array}$ & Direct & $\begin{array}{l}\text { Economic benefits from } \\
\text { continued sand-mining }\end{array}$ \\
\hline $\begin{array}{l}\text { Cape Coast } \\
\text { Municipal } \\
\text { Authority } \\
\end{array}$ & $\begin{array}{l}\text { Key, secondary } \\
\text { and active }\end{array}$ & - & Indirect & $\begin{array}{l}\text { Ecological/environmental/econom } \\
\text { ic health of the lagoon }\end{array}$ \\
\hline $\begin{array}{l}\text { Environmental } \\
\text { Protection } \\
\text { Agency } \\
\end{array}$ & $\begin{array}{l}\text { Key, secondary } \\
\text { and active }\end{array}$ & - & Indirect & $\begin{array}{l}\text { Ecological/environmental health } \\
\text { of the lagoon }\end{array}$ \\
\hline $\begin{array}{l}\text { Traditional } \\
\text { Authorities \& } \\
\text { Believers } \\
\end{array}$ & $\begin{array}{l}\text { Key, secondary } \\
\text { and active }\end{array}$ & $\begin{array}{l}\text { Cultural use of the } \\
\text { lagoon }\end{array}$ & Direct & $\begin{array}{l}\text { Sustenance of the cultural values } \\
\text { of the lagoon }\end{array}$ \\
\hline $\begin{array}{l}\text { Environmental } \\
\text { NGOs and } \\
\text { Groups } \\
\end{array}$ & \begin{tabular}{|l} 
Key and \\
secondary \\
stakeholder \\
\end{tabular} & - & Indirect & $\begin{array}{l}\text { The ecological/environmental } \\
\text { integrity of the lagoon. }\end{array}$ \\
\hline $\begin{array}{l}\text { Tourism/Leisure } \\
\text { Businesses }\end{array}$ & Key but primary & $\begin{array}{l}\text { Beach front } \\
\text { development, leisure } \\
\text { facilities around lagoon, } \\
\text { extensive human impact }\end{array}$ & Direct & $\begin{array}{l}\text { Business/economic benefits, } \\
\text { maintenance of the } \\
\text { environmental/landscape } \\
\text { aesthetics of the lagoon }\end{array}$ \\
\hline \begin{tabular}{l|} 
Media \\
practitioners
\end{tabular} & Secondary & - & Indirect & $\begin{array}{l}\text { General integrity and aesthetics of } \\
\text { the lagoon }\end{array}$ \\
\hline $\begin{array}{l}\text { Central Regional } \\
\text { Coordinating } \\
\text { Council } \\
\end{array}$ & $\begin{array}{l}\text { Key, secondary } \\
\text { and active }\end{array}$ & - & Indirect & $\begin{array}{l}\text { Ecological/environmental/econom } \\
\text { ic health and benefits of the } \\
\text { lagoon }\end{array}$ \\
\hline
\end{tabular}


Table 3. Cont.

\begin{tabular}{|c|c|c|c|c|}
\hline Stakeholder & Characteristics & $\begin{array}{c}\text { Resource Use and } \\
\text { Feedback }\end{array}$ & $\begin{array}{l}\text { Dependency } \\
\text { on Lagoon }\end{array}$ & Interest \\
\hline $\begin{array}{l}\text { Central } \\
\text { Regional } \\
\text { Development } \\
\text { Commission }\end{array}$ & $\begin{array}{l}\text { Key, secondary } \\
\text { and active }\end{array}$ & - & Indirect & $\begin{array}{l}\text { Ecological/environmental/econom } \\
\text { ic health and benefits of the } \\
\text { lagoon }\end{array}$ \\
\hline $\begin{array}{l}\text { Residents } \\
\text { around the } \\
\text { Lagoon }\end{array}$ & $\begin{array}{l}\text { Primary but } \\
\text { passive }\end{array}$ & $\begin{array}{l}\text { Disposal of waste into } \\
\text { lagoon, water } \\
\text { withdrawal, mitigation } \\
\text { of flooding, siltation } \\
\text { eutrophication, algal } \\
\text { bloom }\end{array}$ & Direct & $\begin{array}{l}\text { Waste disposal and access to } \\
\text { water, ecological/environmental/ } \\
\text { socio-economic benefits }\end{array}$ \\
\hline $\begin{array}{l}\text { Academics \& } \\
\text { Researchers }\end{array}$ & $\begin{array}{l}\text { Primary and key; } \\
\text { but can also be } \\
\text { active or passive }\end{array}$ & $\begin{array}{l}\text { Use of flora and fauna, } \\
\text { water or the wetland for } \\
\text { teaching and research, } \\
\text { extensive human impact }\end{array}$ & Indirect & Teaching \& Research \\
\hline Tourists & $\begin{array}{l}\text { Primary but } \\
\text { passive }\end{array}$ & $\begin{array}{l}\text { Leisure, extensive } \\
\text { human impact }\end{array}$ & Indirect & $\begin{array}{l}\text { Leisure and pleasure from the } \\
\text { environmental aesthetics of the } \\
\text { lagoon }\end{array}$ \\
\hline $\begin{array}{l}\text { International } \\
\text { Organizations }\end{array}$ & $\begin{array}{l}\text { Secondary but } \\
\text { key }\end{array}$ & - & Indirect & $\begin{array}{l}\text { Maintenance of the } \\
\text { ecological/environmental and } \\
\text { socio-economic integrity of the } \\
\text { lagoon }\end{array}$ \\
\hline $\begin{array}{l}\text { Other } \\
\text { Government } \\
\text { Agencies and } \\
\text { Departments }\end{array}$ & $\begin{array}{l}\text { Secondary and } \\
\text { key. Can also be } \\
\text { active. }\end{array}$ & - & Indirect & $\begin{array}{l}\text { Ecological/environmental/econom } \\
\text { ic health of the lagoon }\end{array}$ \\
\hline Tourist Board & $\begin{array}{l}\text { Secondary but } \\
\text { key. }\end{array}$ & - & Direct & $\begin{array}{l}\text { Development of the lagoon for } \\
\text { tourism }\end{array}$ \\
\hline $\begin{array}{l}\text { Automobile } \\
\text { Industry }\end{array}$ & $\begin{array}{l}\text { Primary but } \\
\text { passive }\end{array}$ & $\begin{array}{l}\text { Effluent discharge into } \\
\text { lagoon, eutrophication, } \\
\text { algal bloom }\end{array}$ & Indirect & Economic benefits \\
\hline $\begin{array}{l}\text { Small Scale } \\
\text { Vegetable } \\
\text { Farmers } \\
\end{array}$ & $\begin{array}{l}\text { Primary but } \\
\text { passive }\end{array}$ & $\begin{array}{l}\text { Irrigation, changes in } \\
\text { volume of water }\end{array}$ & direct & Economic benefits \\
\hline
\end{tabular}

The study reveals that the most important issues varied with the stakeholder groups as they have different and competing needs. This suggests that the Fosu Lagoon management would be based on values and stakeholder needs.

Management of conflict in resource use has mainly been achieved by both self regulation and a culture of silence. In the case of the former, the fishermen regulate how many fishermen will fish on which day and at what time. This is an informal arrangement with no written regulations enforceable by any law enforcement agency. For example, the fishermen indicated that they alternate among themselves fishing times (morning, late afternoon) and on which days to fish. According to the 
fishermen, this has become the norm because some of them fish also at sea and therefore only use the lagoon when fishing at sea is not possible or economical due to poor fish landing, bad weather conditions or other difficulties related to the sea itself. When fishing at sea resumes, the fishermen who fish at sea know they then have limited fishing times in the lagoon and that is the norm to ensure equity and fairness in terms of deriving economic benefits. The rest of the fisher folk will enforce this. In the rare event of breach of this norm by any fisherman, some of the punitive measures in operation include sharing the fish landing, or the money that accrues from the sale of the fish caught by the culprit fisherman among the rest of the fishermen. This concept of fairness and equity is embedded in the traditional and indigenous culture of many ethnic groups in Ghana. This informal arrangement could be given legal backing to formalize it and make it legally enforceable. Further, this can be strengthened to control the number of fishermen in the lagoon at any point in time to ensure sustainability.

In the case of the latter, fishermen chose to remain silent even though they disagree with the manner in which other stakeholder groups particularly; the residents, District Hospital and St. Augustine's College were using the lagoon. They expressed concern regarding the dumping of refuse (predominantly plastic waste) into the lagoon culminating in siltation, as a result of which the water holding capacity of the lagoon has reduced. The culture of silence may not be sustainable for the reason that the fishermen were accumulating their discontentment within themselves. The critical question is for how long can they continue this practice? The latent anger is a potential recipe for conflict. One fisherman complained that:

'We cannot stop the residents because the municipality has failed to provide the residents with waste management services (waste bins and hauling service)'.

They also complained about the discharge of liquid waste from the District Hospital and St. Augustine's College into the lagoon. They consider the chemicals discharged from the laboratories of both institutions into the lagoon to be responsible for the death and dwindling population of the fish. They indicated that they are helpless because these are government institutions and have therefore not seen the need to make any formal complaint to the municipality or the Environmental Protection Agency. One fisherman further indicated that:

'We take our children to the District Hospital when they are sick. Therefore, we do not want to antagonize them. Some of our children are also students of St. Augustine's College. Hence, we do not want to alienate the school authorities either. Although, none of us or our children has previously been victimized by the District Hospital staff or St. Augustine's College authorities, we still think it is imperative to maintain a cordial relationship with these two groups of stakeholders given the services that they render to us and our children from time to time'.

The mix of stakeholders was changing over time; a situation which introduces a further element of complexity into the management of the lagoon. This result confirms the findings of [29-31]. The factors that account for the changing mix of stakeholders are three-fold: out- and in-migrations, events, and the growing public interest in the lagoon and its potential use. In terms of in- and out-migration, it is evident that some of the residents relocate and may be replaced by others. If this resident is an opinion leader involved in consultations with the municipality (migration rate of opinion leaders, 
usually high income earners, is the highest among all categories of residents), the information and knowledge he gains over the period of consultations, is lost to the community. The loss of information stems from the fact that the channels of communication and information flow between residents and their representatives and among residents are not effective. Given the existence of any previous participatory management arrangements among the former residents, fishermen who no longer use the lagoon and the municipality have not been documented, the new stakeholders who are interested in participatory management of the Fosu Lagoon often do not have information on the scope of consultations with the municipality and how the whole management process has evolved over the years. By the time they really become conversant with the management process, they may have decided to relocate to a new location. The municipality therefore, often was confronted with the emergence of new community representatives in the process of consulting with the community. It is essential to note that some of the low-income earners such as fishermen, whose resident time in the community is usually long (average of 20 years), were over the years, rather content with being represented by opinion leaders who actually migrated often (average resident time of 2 years). To a large extent, this contributes to why most of the fishermen and other residents were not aware of the participatory process. It appears that the fishermen have not realised the fact that this arrangement of being represented by migration-prone opinion leaders feeds into marginalisation and lack of awareness especially when the opinion leaders as representatives of stakeholders were not reporting back to their constituents. There is therefore the need to broaden the base of participation to include more individuals whose resident time in the community is longer.

Second, during events such as the annual Fetu festival, many indigenes of Cape Coast living outside Cape Coast, the residents of Cape Coast and its environs and many other tourists gather around the lagoon to witness the performance of one of the major rituals associated with the celebration of the festival. These groups of stakeholders are transient and seasonal but contribute to the changing mix of stakeholders. The significant feature ceremony 'Bakatue' of the Fetu festival involves cutting through the sand bar separating the Fosu Lagoon and the sea to allow the lagoon access into the sea presumably to bring more fish into the lagoon.

The third factor that accounts for the changing mix of stakeholders is the growing public interest in the lagoon. Lately, apart from the residents and users near the lagoon, some entrepreneurs have taken an interest 'in the use potential' of the lagoon in terms of how to develop the area into a tourist resort. To this group of stakeholders, participation means investment in the Fosu Lagoon area to derive economic benefits; and through public discussions on radio they have been able to position themselves as the alternative to the current management regime instituted by the municipality. A potential conflict of interest lies in the fact that the entrepreneurs are influential and wealthy and could manipulate the panel discussions on radio. However, this challenge is managed in the radio stations by granting access to citizens to contribute to the discussions through live phone-in sessions. Through this mechanism, moderators of radio programmes are able to sample a wide array of opinions on the issues under discussion to balance out the arguments of the entrepreneurs.

The importance that various stakeholders attached to issues such as aesthetics, scientific value, tourist development, industry, commercial fishing, and agriculture and livestock was not uniform across the different interest groups. Across the population, individuals attached the most importance 
and the least importance to commercial fishing and scientific value, respectively. Table 4 summarizes the issues that different interest groups valued as most important.

Table 4. Most important issues in the Fosu Lagoon area for different interest groups of the population.

\begin{tabular}{|c|c|c|c|c|c|c|}
\hline Issue & $\begin{array}{c}\text { Aggregate of } \\
\text { population } \\
\text { (\% of } 600 \\
\text { answers) }\end{array}$ & $\begin{array}{c}\text { Engineers/ } \\
\text { scientists/ } \\
\text { researchers } \\
\text { (\% of } 50 \\
\text { answers) }\end{array}$ & $\begin{array}{c}\text { Small scale } \\
\text { farmers/ } \\
\text { fishermen (\% } \\
\text { of } 250 \text { answers) }\end{array}$ & $\begin{array}{c}\text { Teachers/ } \\
\text { students } \\
\text { (\% of } 100 \\
\text { answers) }\end{array}$ & $\begin{array}{l}\text { Conservationists } \\
\qquad \begin{array}{c}\% \text { of } 40 \\
\text { answers) }\end{array}\end{array}$ & $\begin{array}{c}\text { Technical/ } \\
\text { professionals } \\
\text { (\% of } 150 \\
\text { answers })\end{array}$ \\
\hline Cultural & 6.00 & 5.56 & 9.76 & 10.00 & 15.00 & 12.50 \\
\hline $\begin{array}{l}\text { Scientific } \\
\text { value }\end{array}$ & 1.17 & 40.33 & 2.85 & 15.00 & 12.00 & 8.00 \\
\hline $\begin{array}{l}\text { Tourism } \\
\text { development }\end{array}$ & 12.67 & 4.44 & 8.39 & 14.00 & 15.00 & 3.50 \\
\hline Industry & 17.33 & 7.68 & 6.00 & 16.00 & 2.00 & 50.50 \\
\hline $\begin{array}{l}\text { Commercial } \\
\text { fishing }\end{array}$ & 45.83 & 11.32 & 45.37 & 20.00 & 10.00 & 10.00 \\
\hline Aesthetics & 6.67 & 6.00 & 5.63 & 10.00 & 36.00 & 5.50 \\
\hline $\begin{array}{l}\text { Agric. \& } \\
\text { livestock }\end{array}$ & 10.33 & 24.67 & 22.00 & 15.00 & 10.00 & 10.00 \\
\hline Total & 100 & 100 & 100 & 100 & 100 & 100 \\
\hline
\end{tabular}

The study established that a plethora of stakeholders depend on the Fosu Lagoon either directly or indirectly and this reflects the linkages and complexity of the participatory process. The line between direct and indirect dependency is thin. In fact it is possible that there could be an overlap in some cases. Stakeholders that exhibit direct dependencies on the Fosu Lagoon mainly operate from a small spatial scale and live in proximity with the lagoon. Stakeholders that depend indirectly on the lagoon generally operate from a large spatial scale. The operational scales of the stakeholders appeared to play a critical role in the scope and frequency of information flow and communication among the stakeholders. In general, information flow and communication among the stakeholders operating at the same spatial (horizontal) scale was more effective than information flow and communication among the stakeholders operating across different spatial (vertical) scales. This suggests that space feeds into the effectiveness of the decision making processes and outcomes. Operation of stakeholders across vertical spatial scales detracts from sound decision making unlike operation of stakeholders at the same spatial scale. It would seem that to deal with this problem effectively, all the stakeholders, including Fosu Lagoon users, researchers, and the local authorities whose decisions and/or activities influence actual outcomes, would have to make significant changes in their behaviour, and attitudes. This can be achieved through strengthening of the decentralized government structures at the local level. For instance, the unit committees of the municipality which operates at the lowest level of governance (household level) could be resourced in terms of finance and mobility for effective interaction with the stakeholders in the community.

In many ways, the characteristics of these categories of stakeholders (e.g., as active, passive, key, primary or secondary) could lead to certain types of interactive effects that either enhance or detract 
from sound decision-making. In this case, it detracts from sound decision making since asymmetrical power relations are reflected in the characteristics of the different stakeholders of the Fosu Lagoon. For instance, active stakeholders such as the local authorities (institution) have power to influence decision making unlike passive stakeholders (fishermen) although the latter group is a primary stakeholder. Local authorities have high economic and political power unlike fishermen. In the management of the Fosu Lagoon it appears that structure (institutions such as the local authority) by virtue of economic and political power could thus constrain agency (choices) of less economic and politically endowed stakeholders such as fishermen. This finding is in agreement with the work of [32-35]. Therefore it is important to critically examine the connection and interaction between structure and agency in the management process. The goal is to strengthen agency and demand-driven approaches. According to [33,34],the uneven distribution of power (voting, economic, political) of the different stakeholders when it comes to choices and decision making holds implications for social justice and policy outcomes. Particularly, it has the tendency to compromise the quality and legitimacy of decisions [35]. This calls for improving assessment of the distributional, social and political impacts of policies within the framework of community participation in the management of the Fosu Lagoon. In addressing the problem of 'structure constraining agency' [35] proposes that a three-pronged initiative of government, market and community institutions may be needed. We emphasize the strengthening of community institutions. For example, the community has its own set of informal rules (e.g., self regulation) which appears to be effective. In order to allow the community to make their own choices, the local authority could adapt the mechanism of self regulation into government policy.

Analyses of the interests of different stakeholder groups and impacts of planned interventions on these groups (especially the poor and less powerful) will be required to help ensure that costs are borne and benefits of participation are realised for those intended. An important goal will be to ensure that the interests of disadvantaged and less powerful groups such as fishermen are better articulated and addressed. If strong participation of these groups is to be achieved, it is likely to be through the fostering of empowerment and democratisation processes. The dissimilar behaviour of stakeholders in this case could serve as inputs in agent-based modeling approaches for understanding and testing policy responses to the management of the Fosu Lagoon in a participatory manner [18,19]. This kind of modelling could focus on the representation of agents' behaviours and their systemic relationships with their environment [19]. This could be achieved by examining the interests, motives, cultural beliefs and structural resources that drive agents' actions with regard to the use of the lagoon, by looking at the impact of such human behaviours on the environment and on the natural ecosystems at different scales, and by examining in a co-evolutionary way the impact of such environmental changes on the behaviours of agents $[18,19]$.

The study revealed that, hitherto, the fishermen and the mechanics in particular are only informed of the decisions of the more powerful stakeholders, a situation that results in apathetic attitudes among the former. Some of the fishermen and residents immediately around the lagoon said they have become apathetic to the polluted state of the lagoon since the Municipality has over the years assumed full responsibility of managing it. Three fishermen narrated their experience thus:

'Recently, we questioned the authority of a group of sand miners at the southern part of the lagoon. However, the sand miners indicated that the municipality had given them the permission to do so 
although we think the practice is illegal. When we contacted officials of the municipality to seek clarification on the matter, we were told that the municipality required the sea to enter the lagoon in an experiment to see if the saline condition of the sea will facilitate the process of killing the aquatic weeds (water lily and lettuce) which was proliferating the lagoon, hence the issuance of permit to the sand miners. We were not consulted on the matter before the permit was issued, even though removal of sand on the banks of the lagoon impinges on the sustainability of the Fosu Lagoon. We know from oral tradition handed down to us by our forebears that the elevation of the lagoon is higher than the sea so it is easier for the lagoon to flow into the sea and not the other way around'.

Five fishermen also had this to say:

'The officials of the municipality think that our low literacy level is equivalent to lack of knowledge on lagoon management. But they should not lose sight of the fact that our contact with the Fosu Lagoon dates back to the early 1900s during the days of our forebears. We have learnt through oral tradition handed down from our ancestors that when the Fosu Lagoon dies, we will as a matter of consequence lose our livelihoods'.

This situation demonstrates the fact that the municipality has failed to tap the experiential and indigenous knowledge of the fishermen and the other residents who have been in constant touch with the lagoon. It equally means that, in terms of stakeholder interaction, a key stakeholder (the municipality in this case) uses its political power to make decisions for the passive and/or primary stakeholders (fishermen and mechanics in this case). In fact, the municipality does not consult the primary stakeholders when decisions on the lagoon management are being taken.

All the mechanics who were interviewed stated that:

'The only time that the municipality is interested in our welfare is when tax collection is due'.

To surmount this challenge, it is suggested that civil society groups and/or representatives of the less powerful stakeholders are invited to the decision table to enable them to properly articulate their concerns and expectations. This will be beneficial to the management process.

The findings indicate that certain stakeholders particularly the residents on the periphery of the lagoon are most vulnerable to the feedbacks of lagoon contamination, in terms of the associated health risks. This finding would imply the need to use participation as a social learning process and effective communication platform to improve decision-making, mutual trust and collective will among the stakeholder groups for the sustainable management of the lagoon.

\section{Conclusions}

As exemplified by the case of the Fosu Lagoon, decisions are required every day for determining how ecological resources will be explored, used, and managed by humans. However, decision makers and analysts always have an imperfect understanding of how such systems function and evolve; hence the need to broaden the base of participation. Much as complexity is inherent in all ecological systems, uncertainty is also inherent in every environmental policy decision, whether it is acknowledged or not. Therefore there is the need to involve multiple stakeholders particularly the local communities that have gained substantial management knowledge from their close association with the Fosu Lagoon 
through time. This is essential to reduce conflict and the risk of policy failure. In addition, there can be multiple, potentially conflicting goals for the use of natural resources or for what are the 'best' uses for an ecosystem and its habitats. It does appear that the current management of the Fosu Lagoon is not focused on participation given that most of the stakeholders regardless of whether they have the expertise or not had not taken part in decision-making processes. Therefore, the study concludes that there is scope for broadening the base and improving stakeholder participation in the management of the lagoon. This is necessary to minimize potential conflicts that can arise from the use of ecosystem services that the Fosu Lagoon provides and to ensure the sustainability of the management process. We emphasize the strengthening of community institutions. For example, the community has its own set of informal rules (e.g., self regulation) which appears to be effective. In order to allow the community to make their own choices, the municipality could adapt the mechanism of self regulation into government policy.

\section{Acknowledgements}

We wish to express our profound gratitude to the Senior Research Assistants particularly, Isaac Mbir Bryant and Julia Yeboah, of the Department of Environmental Science of the University of Cape Coast, Ghana for their help during interviews with the stakeholders of the Fosu Lagoon. We wish to thank the Coalition for African Union and Heritage for their support. We also acknowledge the constructive criticisms of three anonymous reviewers which has considerably improved this paper.

\section{References and Notes}

1. Hickey, S.; Mohan, G. Towards participation as transformation: critical themes and challenges. In Participation: From Tyranny to Transformation? Exploring New Approaches to Participation in Development; Hickey, S., Mohan, G., Eds.; Zed Books: London, UK, 2004.

2. Nelson, F.; Agrawal, A. Patronage or participation? Community-Based natural resource management reform in Sub-Saharan Africa. Dev. Change 2008, 39, 557-585.

3. Rodary, E. Mobilizing for nature in southern African community-based conservation policies, or the death of the local. Biodivers. Conserv. 2009, 18, 2585-2600.

4. Blaikie, P. Is small really beautiful? Community-Based natural resource management in Malawi and Botswana. World Dev. 2006, 34, 1942-1957.

5. Smith, J.L. A critical appreciation of the 'bottom-up' approach to sustainable water management: Embracing complexity rather than desirability. Local Environ. 2008, 13, 353-366.

6. Laurie, S.; Hibbard, M. Community-Based natural resource management: Ideals and realities for Oregon Watershed Councils. Soc. Nat. Resour. 2008, 21, 430-440.

7. Tsing, A.; Brosius, J.; Zerner, C. Introduction: Raising questions about communities and conservation. In Communities and Conservation: Histories and Politics of Community-Based Natural Resource Management; Brosius, J., Tsing A., Zerner, C., Eds.; AltaMira Press: New York, NY, USA, 2005.

8. Lockie, S.; Sonnenfeld, D.A. Communities, natural resources, and environments: African and Asian experiences. Local Environ. 2008, 13, 385-391. 
9. Ayoo, C. Community-Based natural resource management in Kenya. Manag. Environ. Qual. 2007, 18, 531-541.

10. Torquiebau, E.; Taylor, R.D. Natural resource management by rural citizens in developing countries: Innovations still required. Biodivers. Conserv. 2009, 18, 2537-2550.

11. Selfa, T.; Endter-Wada, J. The politics of community-based conservation in natural resource management: A focus for international comparative analysis. Environ. Plan. A 2008, 40, 948-965.

12. Gooch, M.; Warburton, J. Building and managing resilience in community-based NRM groups: An Australian case study. Soc. Nat. Resour. 2009, 22, 158-171.

13. Coastal Lagoons: Ecosystem Processes and Modeling for Sustainable Land Use and Development; Gonenc, E., Wolflin, J.P., Eds.; CRC Press: Boca Raton, FL, USA, 2005.

14. Vadineanu, A. Identification of the lagoon ecosystems. In Coastal Lagoons: Ecosystem Processes and Modeling for Sustainable Land Use and Development; Gonenc, E., Wolflin, J.P., Eds.; CRC Press: Boca Raton, FL, USA, 2005.

15. Terwilliger, K.; Wolflin, J.P. Decision making for sustainable development Coastal lagoons. In Ecosystem Processes and Modeling for Sustainable Land Use and Development; Gonenc, E., Wolflin, J.P., Eds.; CRC Press: Boca Raton, FL, USA, 2005.

16. Martinez-Alier, J. The environment as a luxury good or too poor to be green. Ecol. Econ. 1995, 13, 1-10.

17. Clark, C.W; Dickson, N.M. Sustainability Science: The emerging research program. PNAS 2003, 100, 8059-8061.

18. Manderson, A.K. A systems-based framework to examine the multi-contextual application of the sustainability concept. Environ. Dev. Sustain. 2006, 8, 85-97.

19. Boulanger, P.M.; Brechet, T. Models for policy making in sustainable development: The state of the art and perspectives for research. Ecol. Econ. 2005, 55, 337-390.

20. Hahn, R.W. The impact of economics on environmental policy. J. Environ. Econ. Manage. 2000, 39, 375-399.

21. Aswani, S.; Hamilton, R. Integrating indigenous ecological knowledge and customary sea tenure with marine and social science for conservation of bumphead parrotfish (Bolbometopon muricatum) in the Roviana Lagoon, Solomon Islands. Environ. Conserv. 2004, 31, 69-83.

22. Pavlikakis, G.E.; Tsihrintzis, V.A. Integrating humans in ecosystem management using multi-criteria decision making. J. Environ. Manage. 2003, 68, 193-205.

23. Keough, H.L.; Blahna, D.J. Achieving integrative, collaborative ecosystem management. Conserv. Biol. 2006, 20, 1373-1382.

24. Christensen, N.L.; Bartuska, M.; Brown, J.H.; Carpenter, S.; D’Antonio, C.; Francis, R.; Franklin, J.F.; MacMahon, J.A.; Noss, R.F.; Parsons, D.J.; et al. The report of the Ecological Society of America, committee on the scientific basis for ecosystem management. Ecol. Appl. 1996, 6, 665-691.

25. Yaffee, S.L.; Phillips, A.F.; Frentz, I.C.; Hardy, P.W.; Maleki, S.M.; Thorpe, B.E. Ecosystem Management in the United States: An Assessment of Current Experience; Island Press: Washington, DC, USA, 1996.

26. Blay, J.; Dongdem, F. Preliminary observations on the benthic macro fauna of a polluted coastal lagoon in Ghana (West Africa). Trop. Ecol. 1996, 37, 127-133. 
27. Rubin, H.J.; Rubin, I.S. Qualitative Interviewing: The Art of Hearing Data; Sage Publications: Newbury Park, CA, USA, 1997.

28. Grimble, R.; Wellard, W. Stakeholder methodologies in natural resourcemanagement: A review of principles, contexts, experiences and opportunities. Agric. Syst. 1997, 55, 173-193.

29. Freeman, R.E. Strategic Management: A Stakeholder Approach; Pitman: Boston, MA, USA, 1984.

30. Alkhafaji, A.F. A Stakeholder Approach to Governance: Managing a Dynamic Environment; Quorum Books: Westport, CT, USA, 1989.

31. Mitchell, R.; Agle, B.; Wood, D. Towards a theory of stakeholder based identification and salience: Defining of who and what really counts. Acad. Manage. Rev. 1997, 22, 853-886.

32. Gibson, C.C. In pursuit of better policy outcomes. J. Econ. Behav. Organ. 2005, 57, 227-230.

33. Ostrom, E. Coping with the tragedy of the commons. Annu. Rev. Polit. Sci. 1999, 2, 493-535.

34. Ostrom, E. The danger of self-evident truths. PS: Polit. Sci. Polit. 2000, 33, 33-44.

35. Ostrom, E.; Janssen, M.A.; Anderies, M. Going beyond panaceas. PNAS 2007, 104, 176-178.

36. Report of the Second Session of the Intergovernmental Review Meeting on the Implementation of the Global Programme of Action for the Protection of the Marine Environment from Land-Based Activities; United Nations Environment Programme (UNEP): Nairobi, Kenya, 2006; Available online: http://www.gpa.unep.org/documents/igr-2_final_meeting_report_english.pdf (accessed on 1 December 2009).

(C) 2010 by the authors; licensee Molecular Diversity Preservation International, Basel, Switzerland. This article is an open-access article distributed under the terms and conditions of the Creative Commons Attribution license (http://creativecommons.org/licenses/by/3.0/). 